\title{
Article/Artigo
}

\section{Production of cytokine and chemokines by human mononuclear cells and whole blood cells after infection with Trypanosoma cruzi}

\author{
Produção de citocinas e quimiocinas por células mononucleares e células do sangue total \\ humano após infecção com Trypanosoma cruzi
}

\section{Karine Rezende-Oliveira ${ }^{1}$, Ronaldo Rodrigues Sarmento ${ }^{2}$ and Virmondes Rodrigues Junior ${ }^{3}$}

\begin{abstract}
Introduction: The innate immune response is the first mechanism of protection against Trypanosoma cruzi, and the interaction of inflammatory cells with parasite molecules may activate this response and modulate the adaptive immune system. This study aimed to analyze the levels of cytokines and chemokines synthesized by the whole blood cells (WBC) and peripheral blood mononuclear cells (PBMC) of individuals seronegative for Chagas disease after interaction with live T. cruzi trypomastigotes. Methods: IL-12, IL-10, TNF- $\alpha$, TGF- $\beta$, CCL-5, CCL-2, CCL-3, and CXCL- 9 were measured by ELISA. Nitrite was determined by the Griess method. Results: IL-10 was produced at high levels by WBC compared with PBMC, even after incubation with live trypomastigotes. Production of TNF- $\alpha$ by both PBMC and WBC was significantly higher after stimulation with trypomastigotes. Only PBMC produced significantly higher levels of IL12 after parasite stimulation. Stimulation of cultures with trypomastigotes induced an increase of CXCL-9 levels produced by WBC. Nitrite levels produced by PBMC increased after the addition of parasites to the culture. Conclusions: Surface molecules of T. cruzi may induce the production of cytokines and chemokines by cells of the innate immune system through the activation of specific receptors not evaluated in this experiment. The ability to induce IL-12 and TNF- $\alpha$ contributes to shift the adaptive response towards a Th1 profile.
\end{abstract}

Keywords: Trypanosoma cruzi. Innate immunity. Cytokines. Chemokines.

\section{RESUMO}

Introdução: A resposta imune inata é o primeiro mecanismo de proteção contra o Trypanosoma cruzi e a interação de células inflamatórias com moléculas do parasita pode ativar esta resposta e modular a resposta adaptativa. O objetivo deste trabalho foi analisar os níveis de citocinas e quimiocinas sintetizados por células do sangue total (WBC) e células mononucleares do sangue periférico (PBMC) de voluntários soronegativos para doença de Chagas depois da interação com Trypanosoma cruzi. Métodos: IL-12, IL-10, TNF- $\alpha$, TGF- $\beta$, CCL5, CCL2, CCL3, CXC-9 foram avaliados por ELISA. Níveis de nitrito foram determinados pelo método de Griess. Resultados: Foram produzidos altos níveis de IL-10 por WBC quando comparado aos sintetizados por PBMC, inclusive após incubação com tripomastigotas. A produção de TNF- $\alpha$ foi significativamente maior nas culturas de PBMC e WBC após estímulo com o parasita. $\mathrm{O}$ aumento significativo dos níveis de IL-12 foi observado apenas em PBMC depois do estímulo com tripomastigotas. A adição de tripomastigotas nas culturas induziu aumento dos níveis de CXCL9 produzidos por WBC. Os níveis de nitrito produzidos pelos PBMCs de todos os voluntários após a adição de parasito nas culturas aumentaram. Conclusões: Moléculas de superfície do parasito podem induzir a produção de citocinas e quimiocinas pelas células da resposta imune inata através da ativação dos receptores específicos não avaliados neste experimento. A habilidade de induzir IL-12 e TNF- $\alpha$ contribui para direcionar uma resposta imune adaptativa de perfil Th1.

Palavras-chaves: Trypanosoma cruzi. Imunidade inata. Citocinas. Quimiocinas.

1. Disciplinas de Imunologia e Parasitologia, Faculdade de Ciências Integradas do Pontal, Universidade de Uberlândia, Ituiutaba, MG. 2. Disciplina de Biodiagnóstico, Universidade Federal da Paraíba, João Pessoa, PB. 3. Disciplina de Imunologia, Universidade Federal do Triângulo Mineiro, Uberaba, MG Address to: Dra. Karine Rezende de Oliveira. Faculdade de Ciências Integradas do Pontal/UFU. Rua 20, no 1600, Bairro Tupã, 38304-402 Ituiutaba, MG, Brasil.

Phone: 5534 3271-5240; Fax: 5534 3318-5651.

e-mail: karinerezende.oliveira@gmail.com

Received in $02 / 02 / 2011$

Accepted in 09/09/2011

\section{INTRODUCTION}

Trypanosoma cruzi is an intracellular parasite and the causative agent of Chagas disease, an illness that affects about eight million people in Central and South America, with 75 million living in risk areas. The global incidence of the disease is 300,000 new cases per year ${ }^{1,2}$.

Resistance to the parasite observed in humans and in experimental models is due at least in part to the cellular immune response, which is responsible for the production of cytokines, chemokines, and oxygen and nitrogen intermediates ${ }^{3,4}$. In vitro, peripheral blood mononuclear cells (PBMC) can eliminate the parasite after phagocytosis ${ }^{5}$. Studies have demonstrated an increase in the number of PBMC in rats infected with T. cruzi. During the acute phase of infection, the presence of the parasite induces a rapid increase in the production, maturation, and activation of monocytes/macrophages in an attempt to control its replication ${ }^{6}$. In vivo, these cells secrete hydrogen peroxide and nitric oxide (NO) when in contact with the parasite ${ }^{7,8}$.

The interaction of T. cruzi i with macrophages and other cells involved in the innate immune response is mediated by pathogen-specific pattern-recognition receptors such as Toll-like receptors (TLRs). These receptors are activated by molecules present on the surface of the pathogen and induce the synthesis of various proinflammatory cytokines such as interleukin 6 (IL-6), tumor necrosis factor alpha (TNF- $\alpha$ ), and IL-12. In addition, these receptors activate inducible nitric oxide synthase (iNOS) $)^{9-11}$. In this respect, TLR2 plays an important role in the regulation of the initial proinflammatory response during infection ${ }^{12}$. In addition to these cytokines, macrophages and other cells of the innate immune system synthesize immunomodulatory chemokines such as CCL5, CXCL9, CCL2, and CCL3, among others. The result of this interaction is crucial for the evolution of infection, permitting the elimination of the microorganism at an early stage or guiding an adaptive immune response. The immunological mechanisms relevant for both resistance to and 
pathogenesis of Chagas disease are numerous but are still not completely understood, especially in humans. These mechanisms are considered to be important for the control of T. cruzi infection and involve many cell types and mediators of the host's innate and adaptive immune system ${ }^{13,14}$.

In view of the marked importance of the interaction between T. cruzi and the host cell, the objective of the present study was to analyze the levels of cytokines and chemokines produced by cells of the innate immune system of seronegative subjects after the addition of trypomastigote forms of T. cruzi strain Y to the culture. The innate immune response of the host to parasite antigens was evaluated by investigating the synthesis of cytokines (TGF- $\beta$, IL-10, IL-12, and TNF- $\alpha$ ) and chemokines (CCL5, CXCL9, CCL2, and CCL3), as well as the production of NO.

\section{METHODS}

\section{Parasites}

Trypomastigotes of Trypanosoma cruzi strain Y maintained in kidney epithelial cells of the African monkey Cercopithecus aethiops (VERO CCl-81) were studied. The cultures were maintained in RPMI 1640 medium (Sigma, USA) supplemented with 40mg/ml garamycin (Schering-Plough, Brazil) and 5\% fetal bovine serum (Gibco BRL, USA). The medium was changed daily to obtain the maximum number of trypomastigote forms and to eliminate amastigotes in the supernatant.

\section{Subjects}

Sixteen healthy volunteers ranging in age from 18 to 40 years, with negative serology for Chagas disease, were invited to participate in this study. After the volunteers had signed an informed consent form, venous blood $(20 \mathrm{ml})$ was collected from normal noninfected blood donors. Negative serology was confirmed by hemagglutination and enzyme-linked immunosorbent assay (ELISA). Cells were collect from $20 \mathrm{ml}$ heparinized blood. The blood samples were centrifuged at $400 \times$ g on a Ficoll-Hypaque gradient (Pharmacia, Sweden) for $20 \mathrm{~min}$ at room temperature for the separation of mononuclear cells. For the analysis of whole blood cells (without separation of mononuclear cells), samples were centrifuged three times at $300 \times \mathrm{g}$ for $15 \mathrm{~min}$ at $4^{\circ} \mathrm{C}$ and then resuspended in Dulbecco's Modified Eagle Medium supplemented with $5 \%$ fetal bovine serum, gentamicin, and 2-beta mercaptoethanol at a concentration of $2 \times 10^{6}$ cells $/ \mathrm{ml}$. The cells were cultured in a volume of $1,000 \mu \mathrm{l}$ in 24 -well plates and incubated for $24 \mathrm{~h}$ in the presence (5 parasites/ 1 host cell) or absence of live T. cruzi trypomastigote forms. The plates were incubated in an incubator at $37{ }^{\circ} \mathrm{C}$ in an atmosphere enriched with $5 \% \mathrm{CO}_{2}$. After fractionation, $\mathrm{PBMC}$ were washed three times by centrifugation and cultured under the same conditions as described above.

\section{Nitrite measurement}

The Griess method was used for the measurement of nitrite ${ }^{15}$. First, nitrate was reduced to nitrite in buffer containing 1 unit/ $\mathrm{ml}$ nitrate reductase. Next, Griess reagents were prepared by mixing $1 \%$ sulfanilamide (Sigma) and $1 \%$ naphthalenediamine (Sigma) at a proportion of 1:1 in $2.5 \%$ phosphoric acid (Merck, Brazil). For the reaction, $50 \mu \mathrm{l}$ of each dilution of the curve and the supernatant were added to microplate wells and the reaction was read at $540 \mathrm{~nm}$.

\section{Determination of cytokines and chemokines}

Cytokines (IL-12, IL-10, TNF- $\alpha$, and TGF- $\beta$ ) and chemokines (CCL5, CCL2, CCL3, and CXCL9) were determined by ELISA using commercially available monoclonal antibody pairs (BD optEIA). The detection limit of the methods ranged from $2 \mathrm{pg} / \mathrm{ml}$ to $20 \mathrm{pg} / \mathrm{ml}$. High-affinity plates were sensitized with the capture antibody in carbonate buffer and incubated overnight at $4^{\circ} \mathrm{C}$. After washing with phosphate buffered saline (PBS) containing $0.05 \%$ Tween 20 (Sigma), the plates were blocked with PBS containing 2\% bovine serum albumin (BSA) for 4h. Next, the supernatants diluted 1:2 in PBS-BSA were applied concomitantly with recombinant cytokine or chemokine standard ( 0 to $2,000 \mathrm{pg} / \mathrm{ml}$ and 0 to $1,000 \mathrm{pg}$ / $\mathrm{ml}$, respectively, or $250 \mathrm{pg} / \mathrm{ml}$ for IL-12). The plates were incubated for $18 \mathrm{~h}$ at $4^{\circ} \mathrm{C}$. Next, the plates were washed with PBS containing $0.05 \%$ Tween 20 and incubated for $2 \mathrm{~h}$ at room temperature with the biotinylated antibodies specific for each cytokine or chemokine. The plates were again washed and then incubated with peroxidase-conjugated streptavidin for $2 \mathrm{~h}$ at room temperature. Finally, the plates were washed and the reaction was developed with orthophenylenediamine in buffer containing hydroxyurea (Sigma). After color development, the reaction was stopped by the addition of $20 \mu \mathrm{l} 2 \mathrm{M} \mathrm{H}_{2} \mathrm{SO}_{4}$ and the plates were read at $450 \mathrm{~nm}$.

\section{Statistical analysis}

The results were analyzed by the Mann-Whitney and Wilcoxon tests using the Statview for Windows program (Abacus). A p value $<0.05$ was considered to indicate significant differences.

\section{Ethical considerations}

The study protocol was approved by the Ethics Committee of Universidade Federal do Triângulo Mineiro (protocol 0905).

\section{RESULTS}

\section{Cytokine levels}

In the absence of live trypomastigote stimulus, whole blood cells produced higher levels of IL-10 than did PBMC. Addition of the stimulus to whole blood cell cultures induced a significant production of IL-10 by these cells $(\mathrm{p}=0.015)$ (Figure 1A). The high levels of IL-10 produced by whole blood cells may increase the susceptibility of these cells to infection with T. cruzi.

No significant difference in the production of TNF- $\alpha$ was observed between PBMC and whole blood cells. However, the addition of trypomastigotes to the two cell cultures (PBMC and whole blood cells) induced a significant increase in the production of this cytokine ( $p=0.0006$ and $p=0.0002$, respectively) (Figure 1B). TNF- $\alpha$ is produced by cells such as monocytes, macrophages, $\mathrm{B}$ and $\mathrm{T}$ lymphocytes, and polymorphonuclear cells after adhesion and invasion of the microorganism, and is considered an important trigger of the innate immune response.

No differences in the levels of IL-12 produced by PBMC or whole blood cells were observed in the absence of the stimulus. However, there was a significant increase in IL-12 levels produced by PBMC after the addition of trypomastigotes $(p=0.021)$, these cells being important producers of this cytokine (Figure 1C). The production of IL-12 is fundamental for the development of a Th1 immune response, which is associated with the induction of trypanocidal mechanisms. 


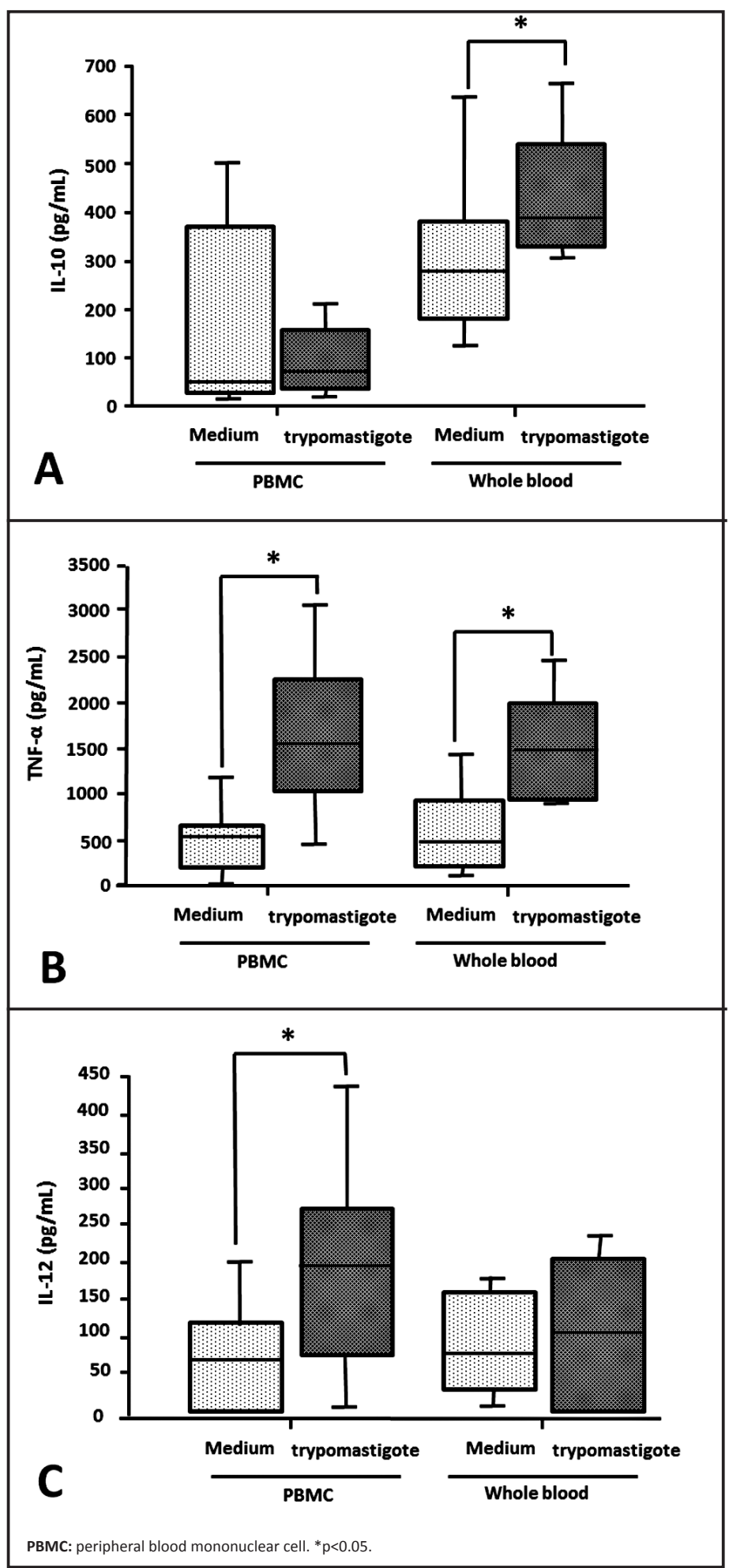

FIGURE 1 - Comparison of the levels of IL-10 (A), TNF- $\alpha$ (B), and IL-12 (C) produced by whole blood cells and mononuclear cells of individuals seronegative for Chagas disease $24 \mathrm{~h}$ after infection with trypomastigotes.

PBMC and whole blood cells did not produce significant levels of TGF- $\beta$ in the presence or absence of the parasite in culture (data not shown).

\section{Chemokine levels}

The presence of the parasite in whole blood cell cultures induced the synthesis of high levels of CXCL9 ( $\mathrm{p}=0.0009)$ (Figure 2). Whole blood cells also produced high levels of CCL3 and CCL2
(Figure 3A and Figure 3B, respectively), as well as CXCL3 and CCL5 (data not shown). Analysis of the production of CCL3 per subject showed that addition of the parasite to whole blood cell cultures induced an increase in the production of this chemokine by these cells $(p=0.1092)$ (Figure 3A). A reduction in individual levels of CCL2 produced by whole blood cells $(p=0.067)$ and PBMC was observed after the addition of trypomastigotes to these cultures (Figure 3B and Figure 3C, respectively). 


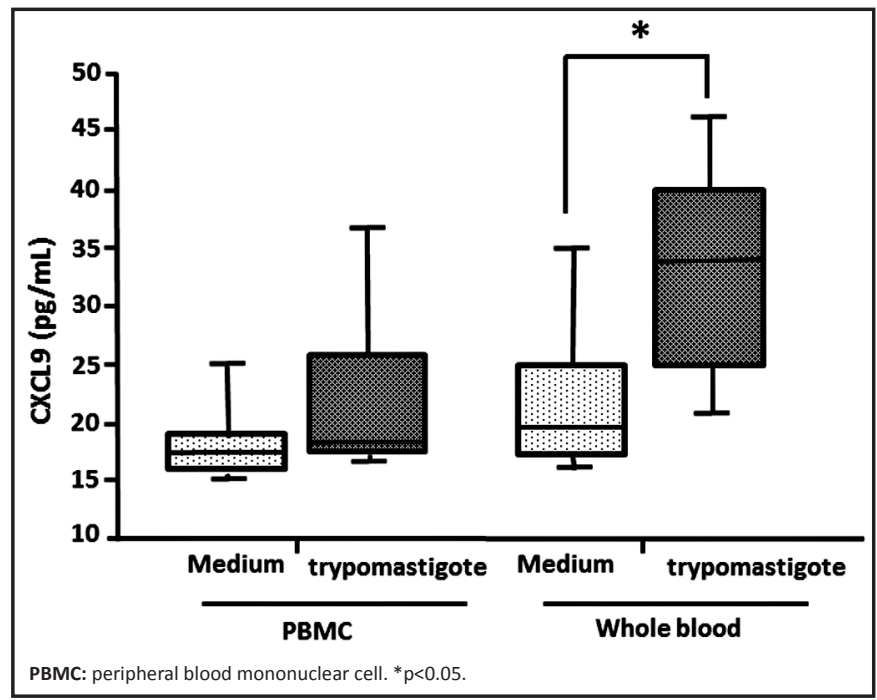

FIGURE 2 - Comparison of the levels of CXCL9 produced by whole blood cells and mononuclear cells of individuals seronegative for Chagas disease $24 \mathrm{~h}$ after infection with trypomastigotes.

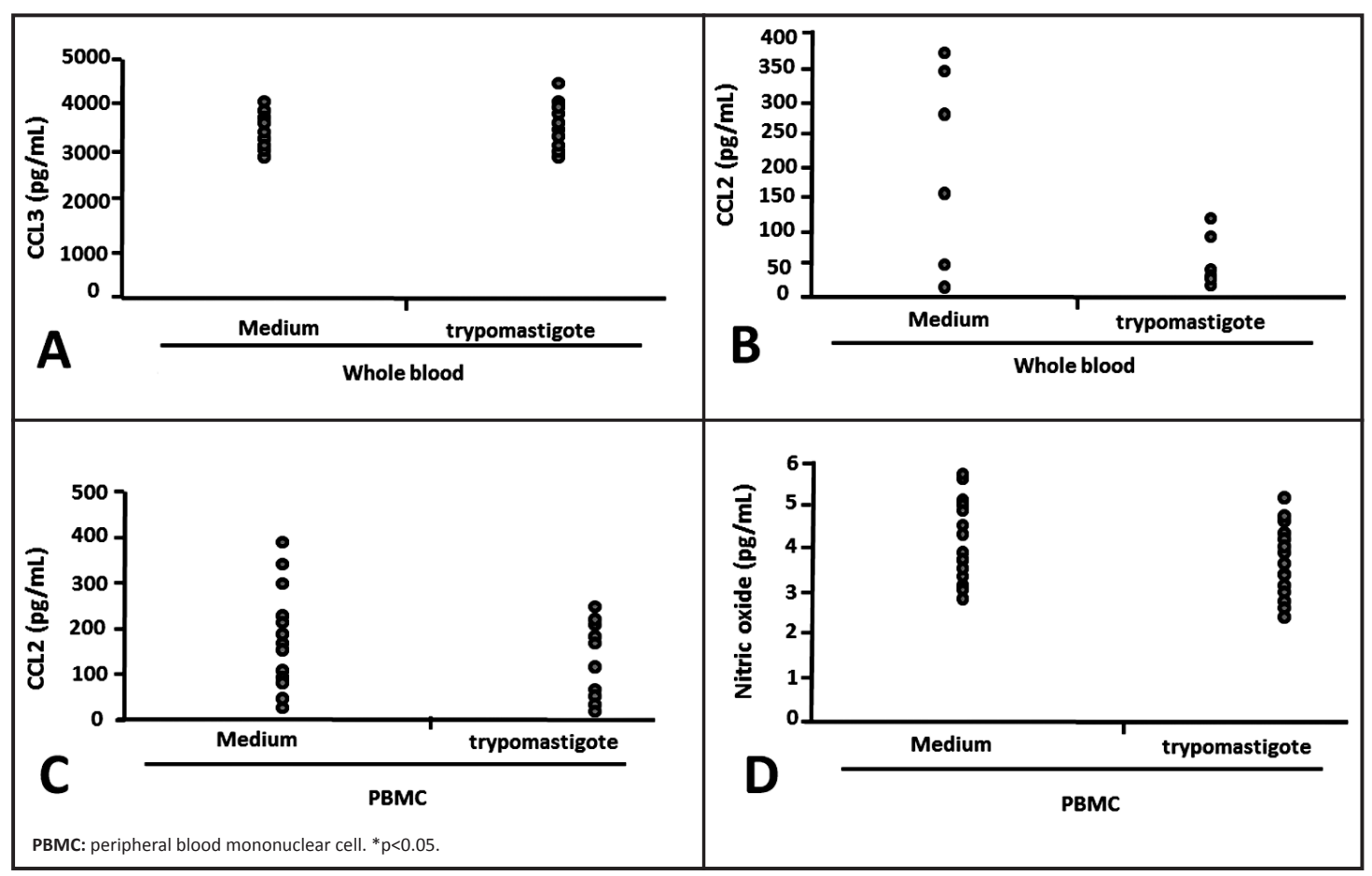

FIGURE 3 - Comparison of the levels of chemokines and nitric oxide produced by whole blood cells (WBC) and peripheral blood mononuclear cells (PBMC) before and after stimulation with trypomastigotes. (A) CCL3, (B) CCL2-PBMC, (C) CCL2-WBC, and (D) nitric oxide.

\section{Nitrite levels}

Whole blood cells produced higher levels of nitrite than did PBMC in the absence of T. cruzi. Neither mononuclear cells nor whole blood cells produced significant levels of nitrite in the presence of trypomastigote forms. However, analysis of nitrite levels produced by PBMC per subject showed that addition of the parasite to the culture reduced nitrite production by these cells $(\mathrm{p}=0.180)$ (Figure 3D). The fact that the supernatant was collected $24 \mathrm{~h}$ after infection may have contributed to the low production of NO.

\section{DIscussion}

Infection with T.cruzi can activate multiple pathways of the innate and adaptive immune system of the host. During the early stages of the disease, contact with T. cruzi trypomastigotes favors the synthesis of regulatory and effector molecules of the immune system, such as cytokines, chemokines, and nitrite ${ }^{7,16-20}$. According to Guiñazú et al. ${ }^{21}$, parasite surface antigens (tGPI-mucin surface molecules) interact with cells of the innate immune system, mainly macrophages, 
and thus contribute to the immunoregulatory processes observed in Chagas disease $e^{4,17,19,22}$. Moreover, monocytes play an important role in the activation of the innate response during the early stages of infection by mediating the cross-talk between the innate and the adaptive immune responses ${ }^{23}$.

In the present study, we analyzed the immune response of PBMC and leukocytes in the blood of healthy volunteers with negative serology for Chagas disease after exposure to live trypomastigote forms of T. cruzi strain Y. Supernatants from $24 \mathrm{~h}$ cultures were used to limit the analysis to the early stages of the parasite-host interaction. In addition, live trypomastigote forms, which are the parasite forms involved in the natural infection of humans, were used. Various surface molecules can serve as receptors for parasite antigens, which induce the synthesis of different cytokines and chemokines ${ }^{24,25}$.

The present study demonstrated the capacity of whole blood cells and PBMC to produce cytokines, chemokines, and nitrite when cultured in the presence of live trypomastigote forms of T. cruzi strain Y. The parasite was able to stimulate the synthesis of proinflammatory (TNF- $\alpha$ ) and anti-inflammatory mediators (IL-10 and TGF- $\beta$ ) that are responsible for the modulation of nitrite synthesis, with consequent effects on trypanocidal capacity ${ }^{26,27}$. The significant production of IL-12 and TNF- $\alpha$ highlights the importance of these two cytokines during the early stages of infection, with IL-12 inducing the differentiation of Th1 lymphocytes and TNF- $\alpha$ activating iNOS. However, a low production of nitrite by these cells was observed, a finding that can be explained by the fact that the cultures basically consisted of monocytes, which are poor producers of nitrite in short-term culture ${ }^{28}$. Furthermore, studies using experimental models have shown that nitrite levels induced by TNF- $\alpha$ alone are not sufficient for an efficient trypanocidal action ${ }^{18}$

In the present study, significantly higher IL-10 levels were observed in whole blood cultures after the addition of live trypomastigotes. IL-10 is known to exert an important anti-inflammatory effect, inhibiting the synthesis of nitrite by macrophages and the production of IFN- $\gamma$ by CD4 $4^{+} \mathrm{T}$ lymphocytes. The effects of this cytokine include the inhibition of a protective immune response and escape of the parasite, thus contributing to the establishment of infection ${ }^{16,29,30}$. The significant increase in the production of IL-10 by whole blood cells after addition of the parasite to the culture suggests that this cytokine indeed contributes to parasite escape. The ability of the parasite to induce IL-10 production suggests the involvement of this cytokine in the early stages of infection.

We also analyzed the production of chemokines, molecules that play an important role in the early events of the immune response and that may also contribute to the nature of the adaptive immune response to be established. Since chemokines play a crucial role in the development of the immune response $\mathrm{e}^{31-33}$, this study also investigated the modulation of these mediator by live trypomastigotes of T. cruzi. A significant increase in CXCL9 and CCL3 and a decrease in CCL2 levels were observed after the addition of live trypomastigotes. The presence of both parasite and other immune system mediators, including cytokines, might influence the expression of these chemokines $^{34,35}$. In experimental models, infection with T. cruzi has been shown to induce the expression of beta chemokines such as CCL3 and CCL2, which are direct inducers of iNOS in macrophages and are involved in parasite control ${ }^{36}$. Studies using experimental models have shown that CXCL9 is correlated with the expression of IFN- $\gamma$ and TNF- $\alpha$ and is involved in the recruitment of inflammatory cells in chagasic myocarditis. Since CXCL9 can induce the migration of IFN- $\gamma$-producing T lymphocytes through CXCR3 receptor signaling ${ }^{37,38}$, the production of this chemokine stimulated by the presence of the parasite may contribute to the activation of a local immune response that is able to control parasite growth. Using an experimental model, Hardison et al. ${ }^{39}$ demonstrated that the chemokines CXCL9 and CCL5 predominate during the acute and chronic phases of experimental Chagas disease and that CXCL9, together with CXCL10, is responsible for the control of replication of T. cruzi.

The present study suggests that the interaction of cells of the innate immune system with live trypomastigote forms of T. cruzi triggers the production of a set of mediators involved in immune response regulation. The synthesis of cytokines and chemokines induced by T. cruzi is decisive for the development of the adaptive immune response involved in parasite control and in the formation of lesions characteristic of the chronic phase of Chagas disease.

\section{CONFLICT OF INTEREST}

The authors declare that there is no conflict of interest.

\section{FINANCIAL SUPPORT}

This study was supported by Coordenação de Aperfeiçoamento de Pessoal de Nivel Superior (CAPES) and Fundação de Amparo a Pesquisa de Minas Gerais (FAPEMIG).

\section{REFERENCES}

1. Kirchhoff LV, Weiss LM, Wittner M, Tanowitz HB. Parasitic diseases of the heart Front Biosci 1998; 9:706-723.

2. World Health Organization. New global effort to eliminate Chagas disease. Weekly Epidemiol Rec 2007; 82:259-260.

3. Muñoz-Fernandez MA, Fernandez, MA, Fresno M. Synergism between tumor necrosis factor-alpha and interferon-gamma on macrophage activation for the killing of intracellular Trypanosoma cruzi through a nitric oxide-dependent mechanism. Eur J Immunol 1992; 22:301-307.

4. Campos MAS, Almeida IC, Takeuchi O, Akira S, Valente EP, Procópio DO, et al Activation of Toll-like receptor-2 by glycosylphosphatidylinositol anchors from a protozoan parasite. J Immunol 2001; 167:416-423.

5. Van Voorhis WC. Coculture of human peripheral blood mononuclear cells with Trypanosoma cruzi leads to proliferation of lymphocytes and cytokine production. J Immunol 1992; 148:239-248.

6. Melo RCN, Machado CRS. Trypanosoma cruzi: peripheral blood monocytes and heart macrophages in the resistance to acute experimental infections in rats. Exp Parasitol 2001; 95:15-23.

7. Silva JS, Aliberti JCS, Martins GA, Souza MA, Souto JT, Pádua MA. The role of IL-12 in experimental Trypanosoma cruzi infection. Braz J Med Biol Res 1998; 31:111-115.

8. Melo RC, Fabrino DL, D'Avila H, Teixeira HC, Ferreira AP. Production of hydrogen peroxide by peripheral blood monocytes and specific macrophages during experimental infection with Trypanosoma cruzi in vivo. Cell Biol Int 2003; 27:853-861

9. Kopp E, Medzhitov R. Recognition of microbial infection by Toll-like receptors Curr Opin Immunol 2003; 15:396-401.

10. Netea MG, Van der Meer JW, Kullberg BJ. Toll-like receptors as an escape mechanism from the host defense. Trends Microbiol 2004; 12:484-488.

11. Flandin JF, Chano F, Descoteaux A. RNA interference reveals a role for TLR2 and TLR3 in the recognition of Leishmania donovani promastigotes by interferongamma-primed macrophages. Eur J Immunol 2006; 36:411-420. 
12. Ropert C, Gazzinelli RT. Regulatory role of Toll-like receptor 2 during infection with Trypanosoma cruzi. J Endotoxin Res 2004; 10:425-430.

13. Silva JS, Machado FS, Martins GA. The role of nitric oxide in the pathogenesis of Chagas disease. Front Biosci 2003; 1:314-325.

14. Golgher D, Gazzinelli RT. Innate and acquired immunity in the pathogenesis of Chagas disease. Autoimmunity 2004; 37:399-409.

15. Green LC, Tannenbaum SR, Goldman P. Nitrate synthesis in the germ-free and conventional rat. Science $1981 ; 212: 56-58$.

16. Hunter CA, Ellis-Neyes LA, Slifer T, Kanaly S, Grünig G, Fort M, et al. IL-10 is required to prevent immune hyperactivity during infection with Trypanosoma cruzi. J Immunol 1997; 158:3311-3316.

17. Aliberti JCS, Cardoso MAG, Martins GA, Gazzinelli RT, Vieira LQ, Silva JS. Interleukin-12 mediates resistance to Trypanosoma cruzi in mice and is produced by murine macrophages in response to live trypomastigotes. Infect Immun 1996; 64:1961-1967.

18. Silva, JS, Vespa, GNR, Cardoso, MAG, Aliberti, JCS, Cunha, FQ. Tumor necrosis factor alpha mediates resistance to Trypanosoma cruzi infection in mice by inducing nitric oxide production in infected gamma interferon-activated macrophages. Infect Immun 1995; 63:4862-67.

19. Talvani A, Ribeiro CS, Aliberti JCS, Michailowsky V, Santos PVA, Murta SMF, et al. Kinetics of cytokine gene expression in experimental chagasic cardiomyopathy: tissue parasitism and endogenous IFN-g as important determinants of chemokine mRNA expression during infection with Trypanosoma cruzi. Microbes Infect $2000 ; 2: 851-866$.

20. Baggiolini $M$, Loetscher P. Chemokines in inflammation and immunity. Immunol Today 2000; $21: 418-420$.

21. Guiñazú N, Pellegrini A, Carrera EA, Aoki MP, Cabanillas AM, Gìronés N, et al. Immunisation with a major Trypanosoma cruzi antigen promotes proinflammatory cytokines, nitric oxide production and increases TLR2 expression. Int J Parasitol 2007; 37:1243-1254

22. Coelho PS, Klein A, Talvani A, Coutinho SF, Takeuchi O, Akira S, et al Glycosylphosphatidylinositol-anchored mucin-like glycoproteins isolated from Trypanosoma cruzi trypomastigotes induced in vivo leukocyte recruitment dependent on MCP-1 production by IFN-g-primed-macrophages. J Leuk Biol 2002; 71:837-844.

23. Vitelli-Avelar DM, Sathler-Avelar R, Teixeira-Carvalho A, Pinto Dias JE, Gontijo D, Faria AM, et al. Strategy to assess the overall cytokine profile of circulating leukocytes and its association with distinct clinical forms of human Chagas disease. Scand J Immunol 2008; 68:516-525.

24. Campos MA, Gazzinelli RT. Trypanosoma cruzi and its components as exogenous mediators of inflammation recognized through Toll-like receptors. Mediators Inflamm 2004; 13:139-143.

25. Willment JA, Brown GD. C-type lectin receptors in antifungal immunity. Trends Microbiol 2008; 16:27-32.

26. Gazzinelli RT, Oswald IP, Hieny S, James SL, Sher A. The microbicidal activity of interferon g-treated macrophages against Trypanosoma cruzi involves an L-argininedependent, nitrogen oxide-mediated mechanism inhibitable by interleukin-10 and transforming growth factor- $\beta$. Eur J Immunol 1992; 22:2501-2506.

27. Abrahamsohn IA. Cytokines in innate and acquired immunity to Trypanosoma cruzi infection. Braz J Med Biol Res 1998; 31:117-121.

28. Biswas SK, Sodhi A, Paul S. Regulation of nitric oxide production by murine peritoneal macrophages treated in vitro with chemokine monocyte chemoattractant protein 1. Nitric Oxide 2001; 5:566-579.

29. Reed SG, Browneell C E, Russo DM, Silva JS, Grabstein KH, Morrissey PJ. IL-10 mediates susceptibility to Trypanosoma cruzi infection. J Immunol 1994; 153:3135-3140.

30. Abrahamsohn IA, Coffman RL. Trypanosoma cruzi: IL-10, TNF, IFN-gamma, and IL-12 regulate innate and acquired immunity to infection. Exp Parasitol 1996; 84:231-244.

31. Villalta F, Zhang Y, Bibb KE, Kappes JC, Lima MF. The cysteine-cysteine family of chemokines RANTES, MIP-1 alpha and MIP-1 beta induce trypanocidal activity in human macrophage via nitric oxide. Infect Immun 1998; 66:4690-4695.

32. Aliberti JCS, Machado FS, Gazzinelli RT, Teixeira MM, Silva JS. Platelet-activating factor induces nitric oxide synthesis in Trypanosoma cruzi-infected macrophages and mediate resistance to parasite infection in mice. Infect Immun 1999; 67:2810-2814.
33. Lima ES, Andrade ZA, Andrade SG. TNF-alpha is expressed at sites of parasite and tissue destruction in the spleen of mice acutely infected with Trypanosoma cruzi. Int J Exp Pathol 2001; 82:327-336.

34. Aliberti JCS, Machado FS, Souto JT, Campanelli AP, Teixeira MM, Gazzinelli RT, et al. $\beta$-Chemokines enhance parasite uptake and promote nitric oxide-dependent microbiostatic activity in murine inflammatory macrophages infected with Trypanosoma cruzi. Infect Immun 1999; 67:4819-4826.

35. Sallusto F, Lenig D, Mackay CR, Lanzavecchia A. Flexible programs of chemokine receptor expression on human polarized T helper 1 and 2 lymphocytes. J Exp Med 1998; 16:875-883.

36. Teixeira MM, Gazzinelli RT, Silva JS. Chemokines, inflammation and Trypanosoma cruzi infection. Trends Parasitol 2002; 18:262-265.

37. Aliberti JCS, Machado FS, Souto JT, Campanelli AP, Teixeira MM, Gazzinelli RT, et al. $\beta$-chemokines enhance parasite uptake and promote nitric oxide-dependent microbistatic activity in murine inflammatory macrophages infected with Trypanosoma cruzi. Infect Immun 1999; 67:4819-4826.

38. Teixeira MM, Gazzinelli RT, Silva JS. Chemokines, inflammation and Trypanosoma cruzi infection. Trends Parasitol 2002; 18:262-265.

39. Hardison JL, Wrightsman RA, Carpenter PM, Lane TE, Manning JE. The chemokines CXCL9 and CXCL10 promote a protective immune response but do not contribute to cardiac inflammation following infection with Trypanosoma cruzi. Infect Immun 2006; 74:125-134. 